\title{
Reflections on the new Scottish innovative child protection system
}

Robyn Agnew

In 1985 I graduated from Auckland College of Education with a CQSW. I worked for ADHB Children's Mental Health Marinoto with a clinical caseload of children and families, becoming a senior social worker. I then worked with much the same client base at Child Youth and Family Services Specialist Services, as a therapist, becoming manager of the service. During this period I sat on the Advisory Group for the new Child Psychotherapy Degree at Auckland University of Technology.

In 1999 I began to develop an interest, with other CYF senior staff, in providing systematic support for work-related harm. I went on to write the policy for Critical Incident Stress Management, incorporating psychological work injury into CYF's Health and Safety Policy. I oversaw the national implementation of these policies based in CYF's Human Resources Group 2000 to 2006; organising and co-training up to 60 staff debriefers and up to 200 Peer Supporters; thus provisioning a national service to CYF staff; providing same-day support and considered follow-up; linking staff to psychological support services for on-going work when required.

In 2006 I left New Zealand for the UK and eventually spent some time in Scotland working as a child protection social worker 2009-10. I now work for the ADHB Starship as a paediatric social worker for Medical Specialties; for the Renal, Gastroenterology and Respiratory Teams; providing transplant and social work assessment and support for families with chronic illness.

I love my work and love the breadth and possibility inherent in the profession.

Recent innovative political decisions have informed social work practice across all departments and all professions. Could this happen in New Zealand?

\section{Abstract}

This paper reflects on my work in Scotland in child protection during 2009 and 2010. It reflects on the Scotland I discovered and The Highlands I worked in. It describes recent innovative political decisions that have informed social work practice across all professions and government departments. It describes the implementation of an essentially simple system, which provides support for every child in need, specific to that need.

It is a system that could positively inform the further development of child protection in New Zealand. Given the current plan to seek ways to 'modernise' Child Youth and Family $(\mathrm{CYF})$, this paper seeks to encourage a debate on the merits of this path-finding Scottish solution to their political, social, ethnic and professional barriers, which could also produce positive outcomes for children in New Zealand (Tolley, 2015).

It describes the overlaying of this approach on top of a professional workforce, despite the silo bureaucracy of service delivery and regardless of professional jealousies protecting individual professions. It describes the responsibilities of all who interact with children and sets certain overlying responsibilities for 'named' persons. In this way the responsibilities for the protection of children is moved from the realm of the social work profession, which is overloaded, as it is currently in New Zealand, and applied directly to all professions that interact with children. 
The Scots have produced a reliable system which strengthens protective mechanisms at the point of service delivery to the child. This in turn develops a reliable and accountable protective society, in which children in need are identified early and supported throughout their contact with different services. The goal is an on-going intervention that can achieve change for the child and allow the child to reach their potential. It is an aspirational system of care, aiming for development of innate potential.

I reflect on the system and the safety it provided to myself as a social worker, the relief of 'sharing' child protection responsibilities with all other professions and the clarity of roles which defines this system.

\section{Introduction}

Minister Anne Tolley recently announced a review of CYF to be conducted by a panel selected by herself (Tolley, 2015). She said that this is to, 'modernise' CYF. Social work representation and child input to this panel was a forgotten late addition. One wonders, therefore, what 'modern' system can be designed in this way, and whether it is in fact primarily a cost-cutting exercise, rather than an innovative solution to New Zealand's children's needs.

CYF has suffered from a long adherence to a policy of providing management staff from the bureaucratic management pool to senior management positions. Successive senior managers have rotated through the department, to the deficit of the children's needs for which the department is funded. The current 'modernisation' strategy is management, not professionally generated. The solutions to the major issue of child abuse and neglect in New Zealand are therefore likely to contain the professional deficits of all substantive management changes to date that the department has made.

Scotland, by contrast, has implemented an aspirational policy and system; this legally protects the name 'social worker'. It is impossible for a social worker to be employed in Scotland by a representative of a profession other than social work. This means professional accountability is maintained throughout the service delivery from worker to supervisor to senior managers. The reason this matters is explored below, but essentially professional not bureaucratic guidance has implemented an aspirational process for Scottish children. This system is based on the United Nations Convention on the Rights of the Child 1989. Signatories have a legal obligation to protect, promote, children's rights; to provision protection and participation (UNCRC).

The Scotland I discovered in the wintry Highlands is deeply conservative, religiously bound and historically proud. It was only recently that it ceased to be a religious and moral crime to hang your washing out on a Sunday, and allow your children to speak on a Sunday. Even with the ancient conquests and integration with Picts, Vikings, Normans and the English, the Scots remain proudly parochial. A certain toughness is needed to survive the climate in the North, where - 16 degrees is the daily norm for weeks of the year. The harshness of the North calls for super-strong washing line pegs called 'storm pegs'. It is a place where it is a duty to fight the wind and win. The people show a kindness of the soul in watching out for one another in this hard land; to survive and keep on struggling despite the loss of jobs. Edinburgh was once the heroin capital of Europe, and drugs are 
still freely available. Whole communities three generations deep can be drug-dependent in the wake of mine closures, loss of income and respect. Robbie Burns still presides over Hogmanay, the traditional new year binge, where men are invited to select clubs, each bringing a bottle of whiskey to drink and be drunk and become poets and 'men' amongst men once more.

The Scottish population 'clearances' in The Highlands occurred over the 1800s. Whole populations of Highland tenant farmers and their communities were displaced for sheep farming, thus decimating the population of The Highlands. The Highlands was depopulated to Texas (where the Scots eventually flourished as cattle barons), Australia and New Zealand (where the Scots settled in Dunedin, the 'Edinburgh of the south', and farmed huge reaches of the South Island, and in Waipu south of Whangarei).

Today The Highlands is still trying to recover its population. When I was there, The Highlands was in receipt of special funding from the European Union, in recognition of its poverty status comparable with other European populations.

The Scotland I came to was marked by the unending kindness of the people, hospitable with a friendly curiosity about New Zealand. Big beautiful mountains with brown, peat-coloured streams and waterfalls; lochs; and empty white sand beaches with turquoise water so cold, where to dip a toe was to freeze it to the bone. This is the geography of my child protection social work in The Highlands of Scotland. This geography birthed the Scottish Enlightenment in Edinburgh, with its ideals of scientific discovery. The Enlightenment stressed human reasoning and scientific method over blind faith and obedience; and was thus in contrast with much of the religious and political order of the day.

This creative cultural legacy and the pursuit of new ways of thinking has perhaps influenced the development of social work practice in Scotland, and it is my hope that this unique approach may influence the development of child protection in New Zealand. Scotland was the place my New Zealand professional supervisor had suggested I would find world-renowned social work.

All countries have their issues and difficulties particular to the climate, geography, history and social evolution. New Zealand, like Scotland, has its own inherent difficulties. Some of the previous attempts at social engineering have created more problems. The concentration on front-end action to respond to child abuse and neglect has led to long-term deficits in state care of children. There has been no professional requirement on the Ministry of Social Development to ensure those children assessed as being in need, receive the therapy and support they require to recover from their detrimental experiences in their families of origin. (Office of Commissioner for Children, 2015). We need a bolder solution than bureaucratic realignment and further privatisation of CYF, to deliver a better future to our children.

Prior to my arrival in The Highlands, a revolution of sorts had occurred across all service delivery areas in Scotland. The Highlands was the 'pathfinder' for the rest of Scotland. When I arrived, new ideas were leading professional changes for child protection and for those children who were in need of support. This was new and aspirational, setting social expectations for all children to achieve their potential. 
This new way of thinking and practice was introduced into an existing highly-skilled professional workforce. Most service delivery workers I encountered were already university-educated and experienced professionals in their different disciplines. This is very different from New Zealand, where the privatisation of intervention and care has often led to the most severely in need being supported by the least professionally qualified, or even worse, released back into the care of unhealthy families, with no positive support structure in situ. This is a breach of the UNCRC 1989 Part One Article 3 number 3 which states,

Parties shall ensure that the institutions, services and facilities responsible for the care or protection of children shall conform with the standards established by competent authorities, particularly in the areas of safety, health, in the number and suitability of their staff, as well as competent supervision (UNCRC, 1989).

The police I worked with were university-educated, and often had a number of years' experience of interviewing children. They were competent, compassionate and kind to the children from whom they were obliged to extract their histories of abuse. I underwent a week's training for the 'Evidential Interviewing' of children. Part of my role was then to join police colleagues in investigating crimes against children.

Any acute event needing urgent intervention was managed jointly by police at inspector level and a social work manager, who would deploy a suitable social worker to work with a police officer. The safety of staff entering homes and other places to conduct interviews in acute situations was the primary concern of the inspector, who briefed the team fully prior to the interview and conducted a debriefing after. This support occurred in addition to my consultation and supervision with my social work manager, who was also my practice supervisor. This again is in strong contrast to New Zealand practice, where children are not interviewed at home or school but in 'specialist environments' by 'specialised' social workers.

Other professions, such as mental health practitioners, early childhood home educators, nursery school teachers, primary school teachers, primary principals, high school counsellors, teachers and high school principals, midwifes and medical staff, all impressed as being child focused and highly professional. All had been trained in the new model of child protection and were expected to follow the new protocols.

\section{Such a simple thing: One child, one plan}

The plan has to be current and up to date, with the objectives and responsibilities for the sector interacting with the child clearly itemised to the responsible person's name. Every child is expected to reach their potential for themselves in their family and in their community, to grow and develop within a caring system of support that could easily be notched up a level to a child protection response if the parents were failing to engage and support their child.

\section{The pre-existing system stayed}

A strongly educated and professional network delivering services to the most remote communities was already in situ. The justice system was presided over by a sheriff, with the power to hear evidence brought by the defender of children's rights (The Scottish Reporter, who is usually a solicitor or barrister), and hear any opposing defence argument. The sheriff then decided on the balance of probability, if the evidence was proven or not - similar to a Family Court process in New Zealand. The Sheriff also presides over criminal court matters. 
Once what is called 'Proof' is established, the Scottish Reporter arranges for a local panel of 'ordinary' community people, with training in child protection, to listen to evidence brought by social workers, schools or anyone with information in relation to a child's need for protection from abuse or neglect. This is called the 'Child's Hearing', and the child's voice needs to be heard in person or their views put forward by a professional. This system interacts with the legal system in a transparent manner lead by the Scottish Reporter.

\section{So what kind of families did I meet?}

They all suffered similar kinds of problems seen the world over and in New Zealand. Nothing unique in the borderline personality mother with no sustainable relationships in her life, but six children from four fathers, the second of which sexually abused his own children as preschoolers. These youngsters were now at school with a new brother to a new immigrant father with a history of domestic assault on the mother and a loving grandfather wealthy with land and sheep who provided a backdrop of support and continuity to the children. The drunken couple with alcohol problems and a preschooler found wandering at 10.00 at night looking for mother, who was comatose on the couch at home. Or the couple who took Christmas heroin, the mother lying unconscious on her bed while her mother looked after the children downstairs. Or the intellectually disabled young mother, with a history of sexual abuse and assault, finding the love of her life, only to discover he was a sadist with sexually perverse inclinations (including the newborn baby in sexual activity); and the mother's subsequent escape from him and her fragile need for safety and security.

Or the young Christian couple, he the son of a minister, she the daughter of religious family, living two stories up in an apartment and rueing the day she left the door open to the postie who saw what he thought was a break-in and trashing of the home. No, this was just a couple living on the edge; with no clear floor space for the baby or the toddler, dirty nappies, open cans and rubbish everywhere; and when the police charged them with neglect, they discovered the husband had sexually abused his sister years before and thus was a risk to his girls.

These were the higher tariff, or harder edge, of child protection cases. I, along with all professional social workers, had a limit of 16 children on my caseload. This provided just enough time to meet the rigor of reporting requirements. New Zealand social workers routinely work far outside these parameters with case-loads so large that the 'critical' case takes precedence over the 'long-term care' requirements (State of Care Report, 2015).

All the Scottish children on my caseload were subject to a plan that was reviewed monthly by the team supporting the family; with the family present. Police, social worker, the school deputy principal with delegated responsibilities for child protection, an adult mental health worker (also the drug and alcohol advisor to the adult, armed with breath-testing kit), a 'vulnerable adult' supporter, a general practitioner, an early childhood educator. If they were delivering services to the family, they were expected to and did attend. The social worker was required to coordinate the meeting and the resulting updated Child Plan. Most children were subject to legal orders managed by the Reporter, for whom a three-month or six-month or annual Child's Hearing to a panel (family present) was required.

\section{Within this rigorous review the needs of the child took precedence}

The first Plan for the child was expected to baseline the child's problems and set the expectations for change. If there were any signs of slippage in the behaviour or the emo- 
tional state of the child thereafter, given the integration of services and their respective practitioners, it was a simple matter to find out what was going on within the family from the multitude of services being provided to them directly in the home or at school. If the parental commitment to the child was challenged to a level that raised risk for the child, then given this same integration of services, it was a simple matter to institute higher levels of safety for the child.

Contrast this system with a recent high-profile West Auckland situation where a child in need was placed with his whanau; not provided with health care despite ACC and Health being aware; and submitted to continuing family violence exposure and serious neglect; and at 13 years faced a murder charge (Stuff, 2015).

In Scotland, the erring parent usually left the home and the competent parent stayed; or a competent adult stayed until the parent had their issue under control again. Thus their struggle with addiction or violence occurred away from the children and therefore did not impact on them. The children were entitled to stay in their own home and at their school.

\section{One simple solution - one child, one plan}

If the issues were health and education, these issues had obvious links and those two agencies wrote the Child's Plan. A social worker (as community consultant and advisor) was detailed to deal with these cases and assist with advice if called upon and attend some meetings; usually with about 150 children in their oversight. The existing two agencies maintained control of the Child's Plan and their respective responsibilities. If three agencies were involved, a social worker would coordinate the Child's Plan and step it up a level. If it was a child protection Child's Plan then it was led by a social worker.

The social worker had to produce the Child's Plan within 14 days of the event or disclosure, and the plan had to include education, health, disability, respite and cultural input. This plan was then reviewed with the parents and with all who had contributed to it, at a formal meeting. The parents were given a copy prior to the meeting as was the Senior Social Worker (offline and responsible for chairing the Plans of several offices/ one of a team called 'Reviewer'). Due to this transparent and integrated approach there were no surprises at the meeting.

If the report included police information about family violence or criminality, then the police would attend and speak. It is possible for some of the information to be heard 'in camera' without the parents present. This formed the baseline Child Plan which was developed, updated and continued to evolve over time as the family's needs changed.

\section{How did these changes come about?}

The child protection system was overloaded. The devolved Scottish Parliament, whilst not yet independent from England in drawing taxes, can set and administer policy. The combined Ministers of Health, Welfare, Police, Education, Justice and Housing, all agreed on a joint child protection policy, where all professions are responsible for the child protection issues of the children they interact with; not only identification of the issues, but the treatment plan for the issues identified.

This policy was formulated and training packages were deployed across all levels of government from the top tier to the lowest level of service provision. When I arrived in The 
Highlands, the final trainings were occurring for lower-tier service levels. These integrated training sessions were for professionals with direct child contact; midwives, teachers, nurses, social workers, all training together.

\section{In addition, every child has a 'Named Person'}

Pre -birth to 10 days old this is the midwife; the public health nurse until the child goes to preschool; then the preschool principal until primary school when it becomes the primary school principal, and at high school the college principal.

These persons are the ones with day-to-day involvement with the child, and are responsible for ensuring that a Child's Plan exists if needed and that this Plan is escalated to a higher level of support from other agencies if the child's needs require it. In this way new child protection concerns are investigated within a background of existing knowledge, with a written history.

\section{What is this supposed to achieve?}

No child falls through the cracks of bureaucracy silos, or has to wait until agencies argue a turf war, or agree jurisdiction; or is delayed by social work overwork and overload.

They call it GIRFEC - Getting it Right for Every Child.

The aims of GIRFEC that are reported on in the Child's Plan are listed below. The Child's Plan tracks the aspirations via the categories as follows:

Confident individuals; successful contributors; successful learners; responsible citizens.

Safe Protected from abuse, neglect, or harm, at home in the school or in the community.

Healthy Having the highest attainable standards of physical and mental health; access to suitable health care and support to make healthy and safe choices.

Achieving Being supported and guided in their learning and in the development of their skills; confidence and self esteem at home, at school and in the community.

Nurtured Having a nurturing place to live, in a family setting with additional help if needed, or where that is not possible, in a suitable care setting.

Active Having opportunities to take part in activities such as play, recreation and sport, which contribute to healthy growth and development at home and in the community.

Respected Should be involved in decisions that affect them. Should have their

Responsible voices heard and should be encouraged to play an active and responsible role in their schools and community.

Included Having help to overcome social, educational, physical and economic inequalities and being accepted as part of the community in which they live and learn. 


\section{Summary}

In this way, one child's potential is protected and supported by the Child Plan. The focus is always on the child and the child's needs, rather than any individual agency, or the parent. Parental compliance to the Child Plan is not legally mandated; however there are consequences for any parental lack of engagement and this may involve the Sheriff's Court and Orders, as it may involve the Family or Criminal Court in New Zealand with similar concerns.

To date, New Zealand's evolution of child protection has been outstripped by the increasing levels of poverty and abuse of children. This in turn contributes to New Zealand children's poor education, health and wellbeing statistics and creates a legacy of societal harm for the future (Child Poverty Action Group, 2013; St John, 2015).

A pathway to solve this complicated situation is further complicated by the turnover of Ministers of Social Development within government; and the change of government ideology from the right to the left and back again. There is no compulsion to provide a solution in New Zealand that outlasts ministerial interest and government commitment.

The practice of outsourcing ministerial advice from contractors with their 'new' ideas also adds to the cocktail of transience of organising ideas. Restructures within Ministry of Social Development have had CYF both inside and outside the Ministry. Such changes ultimately result in failures of service provision to children in need, as one area is focused on to the exclusion of others; and they cause extensive disruption to service delivery during change periods.

The abrupt ending of care at 17 years of age, as in New Zealand, is not the case in Scotland. 'Vulnerable Adult's rights' are recognised by the provision of adult social work. For any interaction with Police, Health or Welfare a 'vulnerable adult supporter' (independent of any agency) is on call for attendance to ensure the rights and entitlements of the vulnerable adult are protected. The provision of adult social work services in Scotland is seen as a necessity. In New Zealand the role of Chief Social Worker for the Ministry of Social Development is a function of the Ministry and limited to children up to the age of 17 years.

Currently, family violence changes are being addressed (Adams, 2015). However the 100,000 Police interventions for family violence do not routinely involve any further support for the children, despite mandatory referral to CYF. Therefore, current solutions to the problem of family violence are again likely to fail long term, as our children grow up exposed to violence with no agency mandated to ensure therapeutic support to break their cycle of learned behaviour.

This paper seeks to encourage the merits of the pathfinding Scottish solution to the political, social, cultural and professional barriers that currently prevent a reliably accountable and protective system for children in New Zealand. As of today, no agency has a responsibility to ensure that all children get the services and treatment they need to recover from the abuses of their lives.

Since I left, the Scots have gone further, with all government departments required to report on the standards set for the wellbeing of children. To date it appears that the system 
is working well with reduced demand on the Reporter and fewer children in care; and lower high-end involvement of child protective services. There has been a quantitative shift from the responsibility for child protection to lie solely with the social work profession, to the involvement of all other professions. Ministerial agreement in Scotland was achieved at the highest level, as a requisite priority. It is unclear to me whether this degree of integration is possible in our parliamentary and civil service in New Zealand.

The aims should be:

- to develop a New Zealand society in which children in need are identified early and supported, whilst there is still hope of interventions that can achieve change for the child,

- that this system be transparent to its users and accountable at all phases of interaction with the child,

- that the system references the child, is central to all child reports and that adults co-signing plans achieve the responsibilities they commit to.

This would require thinking beyond merely 'modernising' CYF. It would look to ensuring aspirational commitment to all New Zealand's children; to realise their potential in their own way, with the degree of support necessary to achieve this; and to design a system to provide this. Is it likely that a senior government bureaucratic team can envisage such a possibility?

The Scottish system has had the experience of a great deal of professional social work thought guiding its inception and integration. This stream of perception was able to engage political will across party lines, and gain universal political will across all departments. It is hard to imagine such a united position in New Zealand politics, where inconvenient child statistics are routinely exposed by NGOs and advocacy groups rather than the government departments who have the responsibility.

The Scottish system required all professionals to accept responsibility for child protection and advocacy. This is a desirable outcome which is still disputed by professions in New Zealand. In New Zealand the professions who refuse to support mandatory reporting continue to maintain an effective barrier to positive change, and are missing their opportunity to transform children's lives to ensure every New Zealand child achieves their potential.

Ultimately, to support long-term positive social change in New Zealand it will be necessary for all professions, political parties and government agencies to be prepared to face the uncomfortable truth of our current social situation and be prepared to envision an aspirational future for all our children and provide the commitment to achieve it over time.

\section{References}

Adams, A. (2015). Strengthening New Zealand's legislative response to family violence; A public discussion document. Retrieved from https: / consultations.justice.govt.nz/policy/family-violence-law/user_uploads/fv-consultation-discussion-document-v2.pdf.

Child Poverty Action Group Inc. (2013). Child abuse: What role does poverty play? Retrieved from www.cpag.org.nz/ resources-publications, June 2013.

GIRFEC. http:/ / www.gov.scot/Topics / People/Young-People/gettingitright/publications.

Office of Commissioner for Children. (2015 ). State of care report. Retrieved from www. occ.org.nz/.

St John, J. (2015). Reflections on Budget 2015. Policy Quarterly, II(3).

Stuff (2015). Kumar killers' sentencing. Retrieved from www.stuff.co.nz / national / crime / 70706222 / Auckland-dairyowners-killer-jailed-for-six-years. 
Tolley, A. (2015). Modernising Child Youth and Family Expert Panel. Retrieved from https:/ / www.msd.govt.nz/ about-msd-and-our-work/newsroom/media-releases / 2015/cyf-panel.html

United Nations Convention on the Rights of the Child. (1989). Retrieved from www.ohchr.org/en/professionalinterest/pages/crc.aspx.

UNCRC. (2013). The foundation of GIRFEC. Retrieved from www.gov.scot/Topics/People/Young-People/gettingitright/publications/uncrc-girfec-report.

Appendix 1. Comparative data: Scotland, The Highlands and New Zealand.

\begin{tabular}{|c|c|c|c|}
\hline & Scotland & Highlands & New Zealand \\
\hline Land Mass & $78,000 \mathrm{~km}^{2}$ & $26,484 \mathrm{~km}^{2}$ & $265,700 \mathrm{~km}^{2}$ \\
\hline Population & 5.2 million & 232,000 & 4.5 million \\
\hline Child Protection & $\begin{array}{l}18,000 * \\
2012 \\
2 \% \text { of the child } \\
\text { population of } \\
1,000,000\end{array}$ & $\begin{array}{l}116^{* * *} \\
2012\end{array}$ & $\begin{array}{l}22,984^{* *} \\
\text { substantiated child } \\
\text { abuse cases } \\
2012-2013\end{array}$ \\
\hline
\end{tabular}

* http:/ / www.scotland.gov.uk/Publications/2013/03/5229/1 viewed 19.03.2014

** www.cyf.govt.nz/about-us / who-we-are-what-we-do/notifications-requiring-furtheraction-back-up.html viewed 19.03.2014

*** http:/ / www.scotland.gov.uk/Publications/2011/09/29133747/2 